\title{
EVALUASI TERHADAP PELAKSANAAN ADMINISTRASI KESISWAAN PADA SEKOLAH MENENGAH PERTAMA NEGERI 1 KUSAN HILIR KABUPATEN TANAH BUMBU
}

\author{
Ade Hermawan \\ STIA Bina Banua Banjarmasin \\ Jalan Pramuka (tembus terminal km. 6) No. 17 Banjarmasin \\ Email : stiabb08@gmail.com
}

\begin{abstract}
The implementation of Student Administration at Kusan Hilir 1 Junior High School includes student planning activities, admission of new students, recording of students in the master book, administration of student attendance, school discipline, student transfer, student organization activities, and administration of graduation and alumni. All student administration activities have been done well by the administration staff of the Kusan Hilir 1 Junior High School. Factors Influencing the Implementation of Student Administration at the 1 Kusan Hilir State Middle School are education of administrative staff and the availability of facilities and infrastructure owned by Kusan Hilir 1 Junior High School.
\end{abstract}

Keyword: Evaluation of Implementation, Student Administration, SMP Negeri 1 Kusan Hilir

Abstrak: Implementasi Administrasi Siswa di SMP Kusan Hilir 1 meliputi kegiatan perencanaan siswa, penerimaan siswa baru, pencatatan siswa dalam buku induk, administrasi kehadiran siswa, disiplin sekolah, pemindahan siswa, kegiatan organisasi siswa, dan administrasi kelulusan dan alumni. Semua kegiatan administrasi siswa telah dilakukan dengan baik oleh staf administrasi SMP 1 Kusan Hilir. Faktor-faktor yang Mempengaruhi Penerapan Administrasi Siswa di Sekolah Menengah Negeri 1 Kusan Hilir adalah pendidikan staf administrasi dan ketersediaan fasilitas dan infrastruktur yang dimiliki oleh SMP 1 Kusan Hilir.

Kata Kunci: Evaluasi Pelaksanaan, Administrasi Kesiswaan, SMP Negeri 1 Kusan Hilir

\section{PENDAHULUAN}

Administrasi sekolah pada lembaga pendidikan umumnya terdiri dari kegiatan administrasi kurikulum, administrasi kesiswaan, administrasi personalia, administrasi sarana pendidikan, administrasi tata laksana sekolah, administrasi keuangan, pengorganisasian sekolah, dan hubungan sekolah dengan masyarakat (humas).

Agar pengelola pendidikan sukses dalam mengelola tugasnya, maka mereka harus menguasai bidang-bidang garapannya dan terampil dalam melaksanakan. Bidang-bidang garapan tersebut merupakan satu kesatuan dan kunci keberhasilan pengelola pendidikan dalam usaha pencapaian tujuan. Oleh karena itu pihak pengelola pendidikan harus betul-betul dapat memahami dan melaksanakan konsep dari semua bidang garapan tersebut.

Administrasi kesiswaan merupakan salah satu bidang pekerjaan administrasi pendidikan. Dalam administrasi peserta didik atau kesiswaan ada berbagai kegiatan yang harus dikelola dengan baik agar proses belajar-mengajar di sekolah dapat berjalan dengan lancar, 
tertib dan teratur. Sehingga dapat mencapai apa yang menjadi tujuan pendidikan di sekolah. Pengelolaan administrasi kesiswaan mencakup kegiatan perencanaan kesiswaan, penerimaan siswa baru, pencatatan siswa dalam buku induk, pengelompokan siswa, kehadiran siswa di sekolah, tata tertib sekolah, mutasi, mengatur organisasi sekolah, kelulusan dan alumni, dan Organisasi Siswa Intra Sekolah (OSIS). Dalam pelaksanaan administrasi kesiswaan tersebut, kepala sekolah, dewan guru, dan staf tata usaha memiliki peranan yang sangat penting dalam menentukan keberhasilan tujuan pendidikan secara efektif dan efisien.

Melihat pentingnya pengelolaan administrasi kesiswaan ini, pada studi pendahuluan di Sekolah Menengah Pertama Negeri 1 Kusan Hilir Kabupaten Tanah Bumbu, penulis menemukan adanya kegiatan yang berkenaan dengan administrasi kesiswaan. Nampaknya belum sepenuhnya terlaksana, seperti kegiatan tata tertib dan Organisasi Siswa Intra Sekolah (OSIS). Hal ini diduga karena ada beberapa faktor yang mempengaruhinya, seperti kepala sekolah, dewan guru, tata usaha dan sarana prasarana yang tersedia.

Berdasarkan latar belakang di atas penulis ingin menganalisa secara jelas tentang pelaksanaan administrasi kesiswaan di Sekolah Menengah Pertama Negeri 1 Kusan Hilir Kabupaten Tanah Bumbu.

\section{LANDASAN TEORI}

Administrasi sangat diperlukan bagi kelangsungan proses belajar mengajar dalam dunia pendidikan. Semua itu tidak lepas dari keaktifan orang-orang yang menguasai administrasi dalam sekolah. Orang sering menganggap enteng administrasi tersebut, padahal kalau administrasi ditangani oleh orang-orang yang kurang terampil maka administrasi tersebut akan berantakan. Orang yang menangani administrasi adalah orang yang sudah terlatih dalam bidangnya (orang yang sudah memiliki ilmu/mendapatkan pelatihan). Administrasi tidak hanya dalam hal keuangan saja tetapi juga dalam kerapian/keteraturan dalam pembukuan.

Administrasi tidak hanya dilakukan dalam waktu tertentu saja tetapi setiap hari secara sistematis. Keberhasilan pendidikan di sekolah harus ditunjang oleh pelayanan administrasi sekolah yang teratur, terarah dan terencana. Di mana dalam pelaksanaannya harus mengikuti arah jaman yang semakin bersaing dan semakin modern. Untuk itu, perlu adanya pembagian tugas ketata-usahaan yang jelas dan terprogram di setiap sekolah. Administrasi kesiswaan adalah usaha dan kegiatan yang meliputi pengaturan tentang administrasi yang berkaitan dengan siswa dalam upaya mengembangkan potensi siswa.

Administrasi bidang kesiswaan mencakup ruang lingkup pencatatan data dan pelaporan. Ditinjau dari segi pembinaan maupun segi penertiban administrasi, masalah pencatatan data dan pelaporan ini sangat penting. Keduanya sama penting dan saling berkaitan, dan untuk itu perlu disediakan format-format untuk menunjang pencatatan dan pelaporan tersebut. Pencatatan data berasal dari beberapa sumber yang diambil dari kegiatan pencatatan selama program pendidikan berlangsung, berikut ini adalah kegiatan administrasi di sekolah/madrasah berdasarkan kalender akademik sebagaimana di bawah ini.

1. Awal tahun pelajaran

a. Penerimaan siswa baru

b. Pendataan calon siswa baru

c. Mengelola data siswa baru

2. Selama tahun pelajaran

a. Membuat dan mengelola buku induk siswa 


\section{REFORMASI}

ISSN 2088-7469 (Paper) ISSN 2407-6864 (Online)

Volume 9 Nomor 1 (2019)

b. Membuat dan mengelola buku klaper

c. Mendata jumlah siswa menurut asal, kelas dan jenis kelamin

d. Jumlah siswa menurut usia, kelas dan jenis kelamin

e. Papan absensi siswa

f. Buku rekapitulasi absensi harian siswa

g. Buku absensi bulanan

h. Buku rekapitulasi tahunan absensi siswa

i. Surat permohonan pindah sekolah

j. Surat keterangan pindah sekolah

k.Mutasi siswa selama semester

3. Akhir Tahun Pelajaran

a. Mendata dan melaporkan calon peserta UAS/UAN

b. Menyiapkan tanda peserta UAS/UAN

c. Mendata dan mengarsipkan tabel peserta dalam prestasi UAS/UAN

d. Pendaftaran masuk kejenjang lebih tinggi

e. Daftar naik kelas/tidak naik kelas

f. Rekapitulasi berhasil dan tidaknya siswa

g. Raport

Dari sinilah betapa pentingnya administrasi kesiswaan bagi sekolah, baik sekolah dasar, menengah dan atas. Khusus dalam bidang adminitrasi kesiswaan. Kepala sekolah selaku koordinator pelaksana administrasi kesiswaan bertanggung jawab penuh atas terlaksananya kegiatan keadministrasian tersebut, diantaranya yaitu kegiatan:

1. Penerimaan siswa baru

2. Pengelompokan siswa

3. Kehadiran dan ketidak hadiran siswa di sekolah

4. Penilaian kemajuan siswa

5. Laporan kemajuan siswa

6. Naik tidaknya siswa

7. Bimbingan kepada siswa

8. Pelayanan kesehatan siswa

9. Mutasi siswa

Data dan informasi yang menggambarkan pertumbuhan dan perkembangan siswa baik perorangan maupun kelompok perlu dihimpun, dicatat dan diperlihara secara cermat dan teratur, sejak pertama kali siswa terdaftar di sekolah sampai siswa tersebut tamat sekolah. Rangkaian kegiatan menghimpun, mencatat dan memelihara data informasi mengenai siswa termasuk dalam bidang pelayanan ketata-usahaan sekolah. Rangkaian kegiatan ini tidak selamanya dikerjakan kepala sekolah tetapi ia melimpahkan sebagian pekerjaan ketata-usahaan kepada guru dan pegawai tata usaha. Ikut sertanya guru dalam hal mengerjakan urusan administrasi sekolah secara keseluruhan adalah wajar, karena administrasi kelas merupakan bagian yang tak terpisahkan daripada administrasi sekolah. Dengan demikian guru khususnya guru kelas dan wali kelas tidak dapat "melepaskan diri" dari urusan administrasi kelas dan sekolah, karena seorang guru sekolah dasar/menengah dan atas, pada hakekatnya adalah seorang "administrator pendidikan". 
Berdasarkan uraian di atas, maka kepala sekolah, kepala tata usaha dan guru bersamasama petugas ketatausahaan lainnya memikul tanggung jawab dalam hal mengurusi adminitrasi kesiswaan khususnya dalam menghimpun, mencatat, memelihara data atau informasi seluruh aspek perkembangan siswa. Salah satu organisasi siswa adalah OSIS (Organisasi Siswa Intra Sekolah) yang resmi diakui dan diselenggarakan oleh sekolah atau madrasah. Dengan ini kegiatan siswa di bawah OSIS berkembang pesat seperti Rohis, Palang Merah Remaja (PMR), Pramuka, Kelompok Kajian Teknologi, dan lain sebagainya.

Oleh karena itu agar organisasi yang ada ini berjalan dengan baik, maka pengaturannya perlu ditata sedemikian rupa agar sesuai dengan tujuan organisasi yaitu pengebangan pengetahuan dan kemampuan penalaran, pengembangan keterampilan dan pengembangan sikap, selaras dengan visi, misi dan tujuan sekolah.

\section{METODE PENELITIAN}

Lokasi penelitian ini di Sekolah Menengah Pertama Negeri 1 Kusan Hilir Kabupaten Tanah Bumbu yang beralamat di jalan 06 Februari Kecamatan Kusan Hilir Kabupaten Tanah Bumbu. Penelitian ini dilaksanakan pada tahun 2018. Metode yang dipergunakan dalam penelitian ini adalah metoda Evaluasi, yaitu suatu metode penelitian yang bertujuan guna melakukan penilaian terhadap keberhasilan pelaksanaan suatu program atau kegiatan. Dalam hal ini adalah penilaian terhadap keberhasilan pekerjaan administrasi kesiswaan pada Sekolah Menengah Pertama Negeri 1 Kusan Hilir.

Populasi dalam penelitian ini adalah seluruh guru PNS yang mengajar pada Sekolah Menengah Pertama Negeri 1 Kusan Hilir yang berjumlah 28 orang. Sampel penelitian diambil dari keseluruhan jumlah populasi, yaitu seluruh guru PNS pada Sekolah Menengah Pertama Negeri 1 Kusan Hilir. Dengan demikian teknik penarikan sampel yang dipergunakan adalah total sampling. Jumlah sampel yang diambil sebanyak 28 orang.

Teknik pengumpulan data yang dipergunakan dalam penelitian ini adalah sebagai berikut:

1. Kuisioner

Yaitu data dikumpulkan dengan menggunakan daftar pertanyaan yang diajukan kepada responden seputar pelayanan Administrasi Kesiswaan yang diberikan oleh Tata Usaha Sekolah Menengah Pertama Negeri 1 Kusan Hilir.

2. Observasi

Yaitu data dikumpulkan dengan cara turun langsung ke lapangan dengan melakukan pengamatan terhadap fenomena yang menjadi masalah penelitian.

3. Dokumentasi

Yaitu data dikumpulkan dari dokumen-dokumen yang berkaitan dengan masalah penelitian.

Data yang berhasil dikumpulkan selanjutnya diolah dan hasilnya dimasukkan ke dalam tabel distribusi frekuensi untuk dinterpretasikan. Teknik analisa data dilakukan secara kualitatif.

\section{HASIL DAN ANALISA}

\section{Evaluasi Pelaksanaan Administrasi Kesiswaan}

Penelitian mengenai evaluasi terhadap Pelaksanaan Administrasi Kesiswaan di Sekolah Menengah Pertama Negeri 1 Kusan Hilir dapat peneliti uraikan sebagai berikut: 


\section{Perencanaan Kesiswaan}

Dalam perencanaan kesiswaan ini ada dua macam yang harus dilaksanakan, yaitu sensus sekolah terhadap calon siswa yang diterima. Mengenai sensus sekolah terhadap calon siswa di Sekolah Menengah Pertama Negeri 1 Kusan Hilir tidak dilaksanakan, sedangkan dalam penentuan jumlah siswa yang akan diterima menjadi siswa baru Sekolah Menengah Pertama Negeri 1 Kusan Hilir memberikan batasan jumlah siswa yang akan diterima yaitu sebanyak 193 orang siswa dari 223 orang calon siswa yang mendaftar pada tahun 2017/2018, sesuai dengan jumlah kelas yang tersedia. Siswa yang diterima itu untuk siswa kelas satu sedangkan kelas dua dan tiga hanya menerima siswa pindahan atau mutasi dari sekolah lain.

Dalam perencanaan kesiswaan kegiatan yang harus dilakukan adalah sensus terhadap calon siswa dan penentuan jumlah siswa yang diterima. Terhadap kegiatan yang pertama Sekolah Menengah Pertama Negeri 1 Kusan Hilir tidak melaksanakannya, hal ini dipengaruhi oleh kepala sekolah yang mempunyai anggapan bahwa sensus terhadap calon siswa itu tidak diperlukan, karena masyarakat sekitar sudah mengenal Sekolah Menengah Pertama Negeri 1 Kusan Hilir. Seharusnya pihak sekolah tetap mengadakan sensus, sebab sensus terhadap calon siswa ini bisa dijadikan indikasi bagi sekolah bersangkutan untuk mengukur minat mereka untuk melanjutkan studinya di sekolah tersebut. Misalnya ditemukan di lingkungan sekolah tersebut banyak calon siswanya, akan tetapi dari sekian calon siswa itu hanya beberapa persen saja yang masuk ke sekolah, dari hasil sensus sekolah ini diketahui penyebab-penyebab minat calon siswa untuk enggan masuk ke sekolah, selanjutnya pihak sekolah mengambil suatu tindakan-tindakan untuk mengadakan perbaikan-perbaikan.

Kemudian mengenai kegiatan kedua, yakni penentuan jumlah calon siswa yang akan masuk, maka dalam hal ini Sekolah Menengah Pertama Negeri 1 Kusan Hilir menentukan jumlah calon siswa yang bisa diterima dengan memperhatikan jumlah kelas yang tersedia.

\section{Penerimaan Siswa Baru}

Pelaksanaan penerimaan siswa baru di Sekolah Menengah Pertama Negeri 1 Kusan Hilir bisa dilaksanakan setelah dibentuk susunan kepanitiaan, pembentukan susunan kepanitiaan ini berdasarkan hasil musyawarah kepala sekolah dengan dewan guru dan staf tata usaha.

Setelah panitia tersebut terbentuk, mulailah melakukan persiapan penerimaan siswa baru dengan membuat ketentuan persyaratan calon siswa baru, seperti surat keterangan kelahiran, surat keterangan kesehatan, surat ketarangan berkelakuan baik dari kepala sekolah asal, fotocopy tanda lulus/STTB yang disahkan, fotocopy rapor kelas tertinggi, membayar biaya pendaftaran, pas foto ukuran $3 \times 4$ dan $4 \times 6$ sebanyak yang diperlukan dan mengisi formulir pendaftaran.

Setelah calon siswa mendaftar dengan memasukkan berkas pendaftaran ke panitia, maka panitia melakukan seleksi terhadap calon siswa tersebut. Setelah penyeleksian selesai barulah ditentukan siswa-siswi yang diterima sebagai siswa-siswi Sekolah Menengah Pertama Negeri 1 Kusan Hilir.

Sebelum dimulai proses belajar mengajar terlebih dahulu pihak sekolah mengadakan suatu upacara penerimaan siswa baru. Dalam upacara tersebut berisi tentang penjelasan hal-hal yang berkenaan dengan pelaksanaan proses belajar mengajar, tata tertib dan perkenalan dengan dewan guru.

Secara umum penerimaan siswa baru di Sekolah Menengah Pertama Negeri 1 Kusan Hilir sudah terlaksana dengan baik, yakni dengan dimulai pembentukan panitia penerimaan 
siswa baru, membuat pedoman pelaksanaan dan menyambut calon siswa baru dalam suatu acara khusus.

Hal demikian disebabkan oleh adanya perhatian dan koordinator kepala sekolah yang sudah baik. Akan tetapi ada beberapa hal yang perlu diperbaiki yaitu dalam penentuan panitia penerimaan siswa baru hendaknya kepada sekolah sebelum menetapkan panitia tersebut sebagai panitia itu hendaknya juga bergiliran. Ini maksudkan agar tidak terjadi kecemburuan sosial di antara guru-guru yang ada, juga dimaksudkan untuk melatih kepemimpinan dan tanggung jawab para guru, bahkan bisa juga dijadikan bahan bagi kepala sekolah untuk mengetahui karakteristik masing-masing guru itu yang berguna sebagai bahan petimbangan dalam mengambil suatu langkah di masa yang akan datang.

Akibat tidak adanya giliran dalam panitia penerimaan siswa baru, maka dewan guru kurang memperhatikan kegiatan tersebut, hal ini disebabkan adanya anggapan bahwa panitia inti saja yang berperan dalam kegiatan penerimaan siswa baru. Kemudian dalam masalah acara penyambutan calon siswa baru hendaknya jangan hanya sekedar penjelasan tentang tata tertib dalam mengikuti proses belajar mengajar dan perkenalan dengan dewan guru, akan tetapi hendaknya digunakan pula sebagai sarana menelusuri kemampuan atau bakat-bakat khusus dari siswa baru tadi. Oleh karena itu, acara-acara ini juga berisi kegiatan pertandinganpertandingan olahraga, pameran seni, lomba pidato dan sebagainya.

\section{Pencatatan Murid dalam Buku Induk}

Setelah siswa baru diterima secara resmi, maka semua siswa tersebut dicatat dalam suatu buku khusus yang disebut buku induk. Dalam buku induk tersebut memuat tentang data identitas siswa-siswi, prestasi belajar serta memberikan nomor induk kepada siswa-siswi yang baru diterima.

Kegiatan pencatatan murid dalam buku induk dapat terlaksana dengan baik. Hal ini didukung oleh adanya tenaga administrasi yang baik, yakni profesional, bertanggung jawab dan moral kerjanya yang cukup tinggi. Ini bisa terjadi karena kepala urusan tata usahanya berpengalaman dalam organisasi dan pernah mengikuti pelatihan administrasi sekolah, dan dibantu oleh staf yang berlatar belakang keterampilan pengelolaan administrasi dan keuangan.

\section{Administrasi Dewan Guru Terhadap Kehadiran Siswa}

Dalam rangka mengontrol presentasi siswa, maka setiap kelas mempunyai daftar hadir dan daftar absensi siswa. Dalam buku daftar hadir itu memuat seluruh siswa yang ada dalam kelas tersebut. Daftar ini biasanya dipegang oleh ketua kelas. Sedangkan untuk daftar absen biasanya diletakkan di dinding samping meja dan kursi guru. Di samping itu pula setiap wali dan guru kelas mempunyai buku daftar hadir dimaksud.

Dalam pelaksanaan kegiatan pembelajaran biasanya guru sebelum memulainya terlebih dahulu mengadakan kontrol presensi siswanya, demikian juga ketika akan mengakhirinya. Kontrol presensi siswa di akhir pelajaran dimaksudkan agar siswa dalam mengikuti pelajaran terhindari dari tidak hadirnya pelajaran masih berlangsung.

Dalam kegiatan ini Sekolah Menengah Pertama Negeri 1 Kusan Hilir sudah dilaksanakan dengan baik, walaupun ada beberapa bagian yang tidak ada. Adapun mengenai kontrol dewan guru terhadap kehadiran siswa ini di awal pelajaran sudah cukup yaitu yang selalu mengontrolnya.

\section{Tata Tertib Sekolah}

Mengenai tata tertib Sekolah Menengah Pertama Negeri 1 Kusan Hilir sudah mempunyai tata tertib tertulis yang harus ditaati siswa. Tata tertib ini disampaikan pada waktu 
memasuki awal pelajaran baru. Sedangkan pencatatan terhadap siswa yang melanggar tata tertib yang dilakukan oleh guru tetapi masih belum dilaksanakan dengan maksimal.

Untuk menerapkan tata tertib di Sekolah Menengah Pertama Negeri 1 Kusan Hilir adalah peran guru BP. Jika ada siswa yang melanggar tata tertib, maka guru BP-lah yang akan memberikan arahan dan bimbingan terhadap siswa tersebut.

Dalam masalah ini penulis menganggap bahwa pengadministrasian terhadap masalah dimaksud masih kurang sempurna, karena tata tertib ini belum terlaksana dengan maksimal dengan dilihat dari banyaknya siswa yang melakukan pelanggaran, mereka biasanya melakukan pelanggaran tentang peraturan seragam sekolah, tidak mengikuti upacara bendera, terlambat hadir ke sekolah, juga sering keluar ketika jam pelajaran berlangsung, mereka sering melakukan pelanggaran karena tidak adanya sanksi yang tegas yang dilakukan oleh pihak sekolah terhadap siswa yang melakukan pelanggaran.

Seharusnya tata tertib ini harus ditekankan kepada siswa supaya kedisiplinan bisa dilaksanakan serta adanya sanksi yang tegas yang bersifat mendidik sehingga timbul rasa segan dan tunduk pada peraturan. Pihak sekolah bisa melakukan aturan piket yang mengoreksi/mencatat siapa saja yang tidak mengikuti apel Senin, siapa yang tidak memakai atribut sekolah, siapa saja yang absen di kelas tiap-tiap mata pelajaran berlangsung, kemudian dilaporkan pada dewan guru, kemudian siswa yang absen tersebut dipanggil dan dimintai keterangan/alasan mereka tidak mengikuti pelajaran.

\section{Mutasi}

Bagi siswa yang akan pindah atau mutasi biasanya diberikan surat pindah sekolah dengan ditandatangani oleh kepala sekolahnya. Dalam surat tersebut biasa berisi tentang alasan kepindahan siswa tersebut.

Setelah itu siswa yang dimutasi itu dicatat dalam sebuah buku yang ukurannya $32 \mathrm{~cm}$, lebar $21 \mathrm{~cm}$, dan tebalnya $1 \mathrm{~cm}$. Dalam buku tersebut memuat alasan kepindahan, tanggal mulai pindah dan sebagainya. Selama penulis melakukan penelitian di Sekolah Menengah Pertama Negeri 1 Kusan Hilir tidak ada siswa yang mutasi masuk atau keluar.

Siswa-siswi yang mengalami hal-hal yang tidak memungkinkan untuk tetap di sekolah ini, mereka akan dimutasi ke sekolah lain. Misalnya mengikuti orang tua yang pindah tempat tugas keluar daerah, melakukan pelanggaran yang dapat mencemarkan nama baik sekolah misalnya berjudi, mabuk-mabukan dan lain-lain.

Selain melakukan mutasi, sekolah ini juga tetap terbuka terhadap siswa yang dimutasi dari sekolah atau sekolah lain. Dalam ini penulis menganggap bahwa pelaksanaannya sudah terlaksana dengan baik.

\section{Mengatur Kegiatan Organisasi}

Dari hasil angket dan wawancara dengan Ketua Organisasi Siswa Intra Sekolah di Sekolah Menengah Pertama Negeri 1 Kusan Hilir bahwa organisasi OSIS ini sudah mempunyai kepengurusan OSIS. Kegiatan ekstra kelas yang dilakukan oleh OSIS di Sekolah Menengah Pertama Negeri 1 Kusan Hilir cukup banyak dan terarah untuk membina keterampilan siswa sesuai dengan bakatnya masing-masing. Siswa bebas menentukan kegiatan mana yang diminati dan sesuai dengan bakatnya. Dengan diadakannya beberapa kegiatan ini diharapkan kegiatan tersebut dapat meningkatkan kreativitas dan ajang untuk mengembangkan kemampuan siswa-siswanya.

Sesuai dengan analisis data di Sekolah Menengah Pertama Negeri 1 Kusan Hilir Organisasi Siswa Intra Sekolah (OSIM) dan kegiatan ekstra kurikuler untuk tahun pelajaran 2015/2016 sudah terlaksana dengan baik. 
OSIS adalah organisasi siswa yang berfungsi sebagai wadah untuk menampung semua aspirasi dan kegiatan-kegiatan siswa di luar kurikulum atau ekstrakurikuler. Di samping itu juga OSIS berfungsi sebagai salah satu bentuk pembinaan terhadap siswa, sehingga dia menjadi warga negara yang baik.

Dalam rangka untuk mewujudkan tujuan pendidikan tersebut salah satunya adalah lewat OSIM. Karena dengan adanya OSIM tersebut siswa akan mendapat pengalamanpengalaman yang sangat berguna bagi pribadi siswa, misalkan pengalaman pemimpinpemimpin, pengalaman bekerja sama, pengalamn hidup demokratis, pengalaman berjiwa toleransi dan pengalaman mengendalikan organisasi. Dengan demikian OSIM mutlak diadakan dan harus mendapat perhatian dan pembinaan yang sebaik-baiknya oleh kepala sekolah atau dewan guru lainnya.

Dari fakta di lapangan menunjukkan bahwa kegiatan-kegiatan ekstra kurikuler maupun kokurikuler tersebut berjalan dengan baik dengan adanya berbagai kegiatan seperti Pramuka, olahraga (Voli, Basket dan tenis meja), Tadarus Alquran, Maulid Habsyi, Rebana, Muhadharah bahasa Arab dan Inggris, Khat dan Pengkajian bahasa Arab, setiap kegiatan dibimbing oleh guru dan pelatih khusus yang telah menguasai setiap kegiatan tersebut. Dengan demikian siswa bebas memilih kegiatan mana yang sesuai dengan minat dan bakatnya masingmasing.

Banyaknya kegiatan di sekolah ini diharapkan dapat memberikan kesempatan kepada siswa-siswinya untuk mengembangkan minat dan bakatnya, menanamkan rasa tanggung jawab, menanamkan rasa kepemimpinan, kesetiakawanan, kerjasama dan kemandirian.

Oleh karena kegiatan ekstra kelas mempunyai fungsi dan arti yang sangat besar dalam menuju tercapainya tujuan pendidikan, maka hendaknya diperlukan pengelolaan kegiatan tersebut sebaik mungkin khususnya pengaturan siswa, peningkatan disiplin para siswa dan semua petugas pelaksanaannya dan sesuai dengan data di lapangan dapat dikatakan bahwa kegiatan OSIM di sekolah ini sudah berjalan dengan baik dan terlaksana dengan lancar.

\section{Kelulusan dan Alumni}

Setelah siswa-siswi secara resmi keluar dari Sekolah Menengah Pertama Negeri 1 Kusan Hilir dengan melalui suatu upacara pelepasan atau pengokohan, maka resmilah mereka menjadi alumni Sekolah Menengah Pertama Negeri 1 Kusan Hilir yang selanjutnya semua alumni dicatat dalam suatu buku khusus.

Adapun jumlah alumni untuk tahun pelajaran 2017/2018 sebanyak 184 orang. Dalam rangka untuk menjalin hubungan dengan para alumni pihak sekolah menjalin lewat pertemuanpertemuan (reuni) yang diselenggarakan oleh para alumni. Akan tetapi pertemuan-pertemuan itu masih kurang dimanfaatkan untuk menunjang kelangsungan sekolah. Kemudian satu hal yang tidak dilaksanakan oleh sekolah ini adalah tidak adanya data alumni yang berprestasi, yang masih melanjutkan studi atau yang sudah bekerja.

Sesuai dengan hasil analisa penulis bahwa masalah kelulusan sudah dilaksanakan dengan baik terlihat dari adanya kegiatan secara resmi keluar dari Sekolah Menengah Pertama Negeri 1 Kusan Hilir dengan melalui suatu upacara pelepasan atau pengokohan, maka resmilah mereka menjadi alumni Sekolah Menengah Pertama Negeri 1 Kusan Hilir yang selanjutnya semua alumni dicatat dalam suatu buku khusus.

Alumni menunjukkan bahwa partisipasi untuk menjalin kebersamaan dan persadaraan sudah terlaksana dengan baik. Dilihat dari pelaksanaan kegiatan reuni yang dilakukan para alumni yang telah dikoordinir oleh kepala sekolah. Biasanya reuni diadakan setiap Bulan 


\section{REFORMASI}

ISSN 2088-7469 (Paper) ISSN 2407-6864 (Online)

Volume 9 Nomor 1 (2019)

Ramadhan sekaligus diadakannya buka puasa bersama dan tiap alumni diundang untuk berhadir.

Dalam masalah kelulusan dan alumni yakni pencatatan para alumni memang sudah terlaksana dengan baik, dalam hal ini pembinaan hubungan dan pencatatan para alumni yang mempunyai prestasi yang bagus atau yang sudah kerja terlaksana dengan baik. Hal ini disebabkan dengan adanya dukungan guru BP yang ada di sekolah tersebut.

Tujuan terpeliharanya hubungan dengan para alumni dimaksudkan untuk kerperluan informasi tentang perguruan tinggi, materi-materi kurikulum yang perlu mendapat perhatian serta hal-hal lain tentang lapangan kerja. Semua itu dijadikan sebagai masukan untuk dijadikan sebagai pertimbangan bagi sekolah dalam menetapkan kebijakan-kebijakan.

\section{Faktor-faktor yang Mempengaruhi Pelaksanaan Administrasi Kesiswaan}

Faktor-faktor yang Mempengaruhi Pelaksanaan Administrasi Kesiswaan adalah sebagai berikut:

\section{Pendidikan Pegawai Tata Usaha}

Tenaga administrasi atau tata usaha di Sekolah Menengah Pertama Negeri 1 Kusan Hilir ada 12 orang. Adapun latar belakang pendidikan mereka adalah Sarjana dan Sekolah Lanjutan Tingkat Atas.

Adapun loyalitas dan moral kerja mereka dalam melaksanakan semua tugas ketatausahaan ini diselesaikan dengan baik, walaupun banyak keluhan-keluhan di antara mereka karena terlalu banyak tanggung jawab yang harus dipikul.

Kemampuannya pegawai tata usaha dalam mengendalikan administrasi kesiswaan di Sekolah Menengah Pertama Negeri 1 Kusan Hilir cukup baik, karena sudah mempunyai kemampuan dan kecakapan dalam mengelola administrasi dengan dilengkapi dengan pembekalan pendidikan dan latihan administrasi sekolah serta diimbangi dengan keaktifannya dalam berorganisasi ketika menjalani perkuliahan maka mereka dapat mengelola urusan administrasi dengan baik.

\section{Sarana dan Prasarana}

Sarana dan prasarana yang ada di sekolah yang berkaitan dengan administrasi kesiswaan meliputi:

a. Sarana ketatausahaan:

1) Ruang tata usaha ada 1 buah berukuran $7 \times 6 \mathrm{~m}$

2) Peralatan tulis menulis, seperti komputer 2 buah dan mesin tik 2 buah semuanya dalam kondisi masih baik.

3) Buku induk kumpulan daftar siswa perkelas daftar penerimaan ijazah, blanko teguran dan blanko keluar.

b. Sarana dan prasarana OSIM dan ruang kepengurusan OSIM

c. Sarana dan prasarana olahraga

1) Peralatan basket seperti lapangan 1buah, bola 2 biji dan keranjang 1 buah.

2) Peralatan volly seperti lapangan 1 buah, bola volley ada 2 buah dan net ada 2 buah.

3) Peralatan tenis meja seperti meja 1 buah, dan bed ada 4 buah.

4) Peralatan bulu tangkis seperti lapangan, net 1 buah dan raket 4 buah.

Sarana dan prasarana ini sudah cukup baik dilihat dengan terpenuhinya kelengkapan kegiatan proses belajar mengajar dan sarana administrasi kesiswaan yang meliputi sarana perpustakaan, sarana UKS, seni dan sarana olahraga. 


\section{REFORMASI}

ISSN 2088-7469 (Paper) ISSN 2407-6864 (Online)

Volume 9 Nomor 1 (2019)

\section{KESIMPULAN}

Dari uraian yang penulis kemukakan pada bagian hasil dan analisa yang mengacu pada tujuan penelitian dapat ditarik kesimpulan sebagai berikut:

1. Pelaksanaan Administrasi Kesiswaan di Sekolah Menengah Pertama Negeri 1 Kusan Hilir meliputi kegiatan perencanaan kesiswaan, penerimaan siswa baru, pencatatan murid dalam buku induk, administrasi kehadiran siswa, tata tertib sekolah, mutasi siswa, kegiatan organisasi siswa, dan administrasi kelulusan dan alumni. Semua kegiatan administrasi kesiswaan tersebut telah dikerjakan dengan baik oleh pegawai tata usaha Sekolah Menengah Pertama Negeri 1 Kusan Hilir.

2. Faktor-faktor yang Mempengaruhi Pelaksanaan Administrasi Kesiswaan pada Sekolah Menengah Pertama Negeri 1 Kusan Hilir adalah pendidikan pegawai Tata Usaha dan ketersediaan sarana dan prasarana yang dimiliki oleh Sekolah Menengah Pertama Negeri 1 Kusan Hilir.

\section{DAFTAR PUSTAKA}

Batinggi, Ahmad. 1999. Manajerial Pelayanan Umum. Universitas Terbuka Jakarta.

Gie, The Liang, 2000. Admnistrasi Perkantoran Modern. Yogyakarta: Leberty.

Gunawan, Ary H. 1996. Administrasi Sekolah (Administrasi Pendidikan Makro). Jakarta: Rineka Cipta.

Handayaningrat. 1996. Pengantar Administrasi Negara. Jakrta: Ghalia Indonesia.

Hasibuan, Melayu. 1999. Organisasi dan Motivasi Dasar Peningkatan Produktivitas. Jakarta: Bumi Aksara.

Moenir, H.A.S. 2002. Manajemen Pelayanan Umum di Indonesia. Jakarta: Bumi Aksara.

Munir. 2000. Manajemen Pelayanan Publik. Jakarta: Bina Aksara.

Siagian SP. 1982. Filsafat Organisasi. Jakarta: Gunung Agung.

Suryo, Subroto. 1998. Dimensi-Dimensi Administrasi Pendidikan di Sekolah. Jakarta: Bina Aksara.

Sutarto. 1989. Administrasi Kantor. Jakrta: Ghalia Indonesia.

Sutopo. 2003. Pelayanan Prima. Jakarta: Lembaga Administrasi Negara. 